\title{
Confrontations with Colonialism: Resistance, Revivalism and Reform under British Rule in Sri Lanka 1796-1920 (Vol. I) by P. V. J. Jayasekera (Colombo: Vijitha Yapa, 2017), Rs. 1500/-.
}

Reviewed by C. R. de Silva*

Former Professor of History, University of Peradeniya and Professor Emeritus, Old Dominion University, Norfolk, Virginia, USA.

In one of the most challenging and thought-provoking history books published in Sri Lanka in the last decade, P. V. J. Jayasekera has used a wide variety of sources to challenge a number of existing interpretations relating to Sri Lanka under British colonial rule in the nineteenth century. While the book is based partly on his own doctoral dissertation completed in 1970, in Jayasekera's own words "The scope and the foci of the original study have been substantially changed" (p. ix) in view of new theoretical approaches in the study of colonial history and the debates on history arising out of the recent ethnic conflict. Jayasekera has also carefully taken into account historical research on Sri Lanka published in the long period since he completed his dissertation. Readers should note that despite the title, Jayasekera has consciously avoided any attempt "to cover the confrontations of the Sri Lankan Tamil society with colonialism" (p. xxvii) and that, with the exception of brief references in the concluding section, information on Muslim-Buddhist relations will come to us only in the forthcoming second volume.

In the introduction to his work, Jayasekera briefly reviews theoretical approaches to the study of colonialism (postmodern, postcolonial and subaltern theories) and makes the case that Sri Lankan historians (unlike the historians of India), have "failed to bring about a radical departure in modern Sri Lankan historiography" (p. xxvi). His argument is that Sri Lankan historians have, so far, generally been complicit with perpetuating "the legitimizing ideology of colonialism". He points out that although "a beginning was made in the late 1960s in the study of indigenous social and cultural movements", even in the third volume of the University of Ceylon: History of Ceylon in 1973, most of the space is "devoted to elaborate institutional development and policy formulations of British rulers" (p. xxv). This work, therefore, should be seen, at least in part, as an attempt to recognise the formative influence of challenges to British colonialism including passive resistance, rebellions and reformist movements. It could have benefitted from the more nuanced analysis of Nira Wickramasinghe (2006), which is not mentioned in the bibliography of the book under review. While Wickramasinghe's analysis is largely on the twentieth century, about a third of her book covers the period that Jayasekera surveys and Wickramasinghe's work, like Jayasekera's, deals with the colonial impact, resistance, new methods of communication and new religious practices.

In the first part of his book, Jayasekera contests the prevailing view that the colonial state was transformed into a 'laissez-faire' state by the Colebrooke-Cameron reforms implemented in the 1830s and beyond. While historians have differed on the extent of the development of a laissez-faire state under British rule, Jayasekera has provided the most comprehensive challenge so far, to the view that the role of the colonial state was that of a 'night watchman'. He points out that the key to British policy in Sri Lanka was not some overarching ideology (though of course the British came with preconceptions of their superiority), but,

"the direct involvement of the British bourgeoisie in the country's production process, trade, 
transport, banking and insurance, all of which were associated with the plantation system" (p. 42).

He brings in a wealth of evidence to show how the European economic stakeholders influenced and skewed policy decisions of the colonial state to benefit themselves in areas such as taxation, labour supply and land policy. Previous historians have noted the influence of local European entrepreneurs and the complicity of the colonial state with their interests. However, Jayasekera provides abundant evidence on how policies of the colonial state, fashioned through an alliance of British bureaucrats, planters and entrepreneurs in matters such as the grain tax and land ownership, led to increased impoverishment of the peasantry and the growth of landlessness. Even in the area of laws protecting immigration labor in the plantations, Jayasekera maintains that,

"the combination of European planters, Government Agents, Magistrates and Police made these laws ineffective. Most planters were Justices of Peace and their testimony found ready acceptance in courts. Besides, the representatives of the Planters' Association and the Chamber of Commerce exerted so much power and influence over the government that provincial Government Agents and judicial officers were intimidated to take the side of the planters" (p. 57).

While his criticism of policies in the late $19^{\text {th }}$ century on state investment in restoring big reservoirs might be open to debate, Jayasekera makes the key point that British investment on irrigation works for peasants was a fraction of the taxes collected from them and that the colonial state made use of 'rajakariya' obligations on peasants to construct roads and public works that mostly benefited European planters. Through his analysis of the grain tax Jayasekera underlines the picture of an exploitative colonial state. There was a tax on paddy and dry grains. All commercial crops were exempt from this tax. The evictions and landlessness that resulted from the inability of a number of peasants to pay the tax is documented in the volume, as is the story of the debates that eventually led to its abolition at the end of the century. At the end of this part of his book, Jayasekera briefly mentions the groups who benefitted from changes under British rule-local functionaries who collaborated with the administration, local businessmen and Indian import merchants and moneylenders.

In the second part of Volume 1, Jayasekera uses the term 'Christian colonialism', "to highlight the vital role of Christianity in European colonialism and its project of spiritual and cultural domination" (p. 180). He carefully documents how Christian missions provided not only support for colonial rule, but also the motivating force to try to eliminate other faiths in areas of Sri Lanka under Portuguese and Dutch rule. Using the work of earlier historians, Jayasekera also carefully provides instances of resistance - both violent and passive- to Christian hegemony. Jayasekera makes the point that the "reemergence of a properly ordained, disciplined and learned sangha in the precolonial tradition" (p. 216) in the Kandyan kingdom had its impact on increased Buddhist religiosity in areas under colonial rule. He could have strengthened his argument if he had drawn from the excellent analysis of Anne M. Blackburn (2001) on Buddhist learning in the late eighteenth century. Looking at the nineteenth century, Jayasekera shows how the rise of new 'reformed' Buddhist sects with valid ordination catered to the needs of non-Goyigama Buddhists of the low country and strengthened their hand in the struggle for religious freedom in a state pervaded by Evangelical Christianity.

Indeed, Jayasekera goes beyond previous analysts in contending that Christianity was deeply implicated in British colonial policies through the nineteenth century:

"The 'Bible and Flag' were so inextricably merged that for many Britishers the Empire was a gift of God and Britain possessed a superior truth and a responsibility to transform colonised societies that were steeped in superstition, ignorance, etc." (pp. 232-233).

He carefully illustrates how Christian missionaries received state support. In the early nineteenth century,

"The missionaries and British officials used the Mudaliyars and headmen to summon villages for baptism, to assist in Christian marriage registration, opening of schools, attend their public preaching and to persuade villagers to send their children to missionary schools" (p. 242).

He shows how missionaries continued to receive state support (in the field of education and elsewhere) throughout the nineteenth century. Five of the nine members of the Central School Commission of 1841 were representatives of missionary organisations. The author points out that by the end of the 1870 s,

"The missionaries and teachers trained by them continued to dominate the entire system imparting exclusive Christian scriptural instruction overruling the half-hearted attempt of the government to introduce a restriction of religious instruction to the first hour of the school day or to give the parents the discretion" (p. 275). 
Jayasekera also points out that, despite the disadvantages under which Buddhists operated, Buddhist resistance to proselytisation grew in the late $18^{\text {th }}$ and early $19^{\text {th }}$ centuries. He states that,

"the activism that Bentara Attadassi brought to the early Buddhist resistance was continued with greater militancy by Migettuwatte from the 1840s" (p. 304).

The acquisition of printing presses by Buddhist leaders in the 1860s and series of public debates with the Christians in the 1860s and 1870s effectively challenged "the spiritual mission of Christianity and the civilising mission of colonialism" (p. 316).

In the last part of Volume 1, Jayasekera makes a convincing case for the redefinition of the role of the Theosophists in the so-called 'Buddhist revival of the late $19^{\text {th }}$ century'. Jayasekera's own analysis of Buddhist activity in the early $19^{\text {th }}$ century strengthens the argument already made by some previous analysts that the 'revival' had earlier origins.

Jayasekera makes some important contributions to the historiography of Sri Lanka. He points out that while Theosophists assisted the Buddhists in challenging colonial policy that favored Christian missions, by the time they arrived, Buddhists had already begun to "play an assertive role in confronting Christian colonial difference" (p. 371) reclaiming control over Buddhist sacred sites and reasserting the right of public performance of traditional ceremonies and rituals. $\mathrm{He}$ asserts that,

"In the early stages, the Theosophists had to act constantly under the guidance and vigilance of the leading sangha and the enthusiastic reception accorded to them in all parts of the country was in fact to a large extent, the work of the sangha" (p. 375).

Jayasekera does acknowledge the role of the Theosophists in undermining Christian claims to a superior religious truth and gives them credit for undermining the virtual Christian monopoly on education. Nevertheless, his analysis could have profited from a reading of Ann Blackburn's Locations of Buddhism (2010). Working through a study of the life and achievements of Rev. Hikkaduwe Sri Sumangala, Blackburn (2010) presents a nuanced picture of agency and Buddhist activity in the second half of the nineteenth century.

Like some other scholars, Jayasekera also rejects the use of the term 'Protestant Buddhism' to explain changes in Buddhism during this period. Gananath Obeyesekere (1972: p. 62) defined it as follows:

“The term 'Protestant Buddhism' in my usage has two meanings. (a) As we have pointed out many of its norms and organisational forms are historical derivatives from Protestant Christianity, (b) More importantly, from the contemporary point of view, it is a protest against Christianity and its associated Western political dominance prior to independence".

Jayasekera points to instances in other countries where traditional religious groups promoted 'modern' thinking and practice before the impact of colonial rule. According to him,

"Protestant Buddhism thesis" he states "amounts to an attempt to explain outward changes in Buddhism in keeping with complex socioeconomic developments and the process of westernization under European colonialism in terms of a hypothetical and narrowly conceived process of religious assimilation" (p. 415) (Jayasekera, 2017: p. 412).

Like Charles Hallisey (1994), Jayasekera sees this concept as minimising the scope for local achievement.

Jayasekera also assesses the divisions and weaknesses within the Buddhist movement. On the whole, he is accurate in his assessment of these fissures and vulnerabilities. He correctly points out that occasionally caste rivalries proved to be more salient than religious differences. He also points out that while,

"social networks of westernised Buddhist leaders normally transcended religious differences" (p. 453),

"Buddhist businessmen had always been the enthusiastic supporters of the religious revival with liberal contributions towards Buddhist funds and active participation in various organizations" (p. 455).

These factors impacted on the ways in which elements of the Buddhist revival fed the growing nationalist movement.

There are a few areas in which we might legitimately question Jayasekera's conclusions. I suggest that here is more evidence of the 'laicization' of the leadership of the Buddhist movement at the turn of the century than 
Jayasekera (and Blackburn, 2010) admits. Jayasekera states,

"Neither the new lay Buddhist leaders nor the Theosophists could interfere with the traditional learning and training imparted by the pirivenas" (p. 401).

Nevertheless, the Prachina Bhashopakara Samagama, which developed out of the Committee of Oriental Studies that Education Director S. M. Burrows put together in 1902, began to have a crucial impact on the curriculum of the piriven after 1903 through its western-style prachina examinations.

On occasion, one sometimes wishes that he were more explicit in clarifying when he is summarising his sources and when he is making an assertion of his own views. For example,

"The argument of alien exploitation of the Sinhalese was directed mostly at the Muslim traders both Sri Lankan and Indian. The Muslims who had never enjoyed a reputation for fair trade were not merely traders but money lenders, purchases of all local produce in rural areas and often 'land grabbers'. Although the rival Sinhalese from the low country were adopting the same business methods, the Muslims as the more established traders came to be accused of ruthless exploitation of the Sinhalese masses" (p. 457).

It is almost certain that the last sentence of the quoted section represents Jayasekera's views and that the previous sentence stating that Muslims never had reputation for fair trade simply summarises what was in his sources but he could have made that clearer.
However, these reservations should not detract from what is essentially a scholarly, provocative volume. This is a book that should be in every major library and read by everyone researching on British colonial rule in Sri Lanka. It is copiously documented with over 120 pages of footnotes in a volume just short of 600 pages. Despite the few omissions that I have highlighted earlier, the bibliography is quite comprehensive. We can only hope that volume two will match it both in historical analysis and readiness to court controversy.

\section{REFERENCES}

Blackburn, A. M. (2001) Buddhist Learning and Textual Practice in Eighteenth Century Lankan Monastic Culture, Princeton: Princeton University Press.

Blackburn, A. M. (2010) Locations of Buddhism: Colonialism and Modernity in Sri Lanka, Colombo: Social Scientists' Association.

D O I : h t t p s : / / d o i.o r g/ $10.7208 /$ chicago/9780226055091.001.0001

Hallisey, C. (1994) In Defense of Rather Fragile and Local Achievement: Reflections on the Work of Gurulugomi, In Reynolds, F. E. \& Tracy, D. (eds) Religion and Practical Reason: New Essays in the Comparative Philosophy of Religion, Albany: University of New York Press.

Obeyesekere, G. (1972) Religious Symbolism and Political Change in Ceylon, In Obeysekere, G., Reynolds, F. \& Smith, B. (eds) The Two Wheels of Dhamma: Essays on the Theravada Tradition in India and Ceylon, PA: American Academy of Religion.

Wickramasinghe, N. (2006) Sri Lanka in the Modern Age: A History of Contested Identities, Honolulu: University of Hawaii Press. 